\title{
When is the best time to apply post-harvest nitrogen fertiliser?
}

Paula Ibell 1,a, Ian Bally ${ }^{1}$, Carole Wright ${ }^{1}$ and Cheryl Maddox ${ }^{1}$

Department of Agriculture, Fisheries and Forestry, 28 Peters St, Mareeba, Qld;

\begin{abstract}
The effect of application timing of nitrogen to mango trees was investigated over 3 years to determine if pre-harvest applications of $\mathrm{N}$ affected fruit quality, canopy growth, flowering and tree yield in 8 year-old Kensington Pride (KP) and R2E2 mango trees growing in Far North Queensland. The experiment consisted of six treatments where a total of $156 \mathrm{~g}$ $\mathrm{N}$ per tree was applied as 340 grams of urea at different application times and proportions. The treatments were applied as 1) $100 \%$ post-harvest (control), 2) $50 \% 2$ weeks preharvest plus 50\% 2 weeks post-harvest, 3) 35\% 2 weeks pre-harvest plus $65 \% 2$ weeks post-harvest, 4) 65\% 2 weeks pre-harvest plus 35\% 2 weeks post-harvest, 5) 35\% 4 weeks pre-harvest plus $65 \% 4$ weeks post-harvest, and 6) 65\% 4 weeks pre-harvest plus $35 \% 4$ weeks post-harvest. The results indicated that the pre-harvest applications of $\mathrm{N}$ did not significantly affect tree or orchard yield, fruit weight, size or number, nor did it negatively influence background skin colour or disease incidence at eating ripe in either variety, when compared to the control $(100 \% \mathrm{~N}$ added post-harvest). In the R2E2 trees, treatments 4 and $6 \mathrm{had}$ an increased total panicle count. For the KP trees, pre-harvest applications of $\mathrm{N}$ in treatments 5, 6, 4 and 2 had increased stages of floral development when compared to the control trees, at the early stages of flowering. These results indicate applications of $\mathrm{N}$ fertiliser prior to harvest can positively influence seasonal vegetative growth and early inflorescence development but responses are variety specific. Therefore, $\mathrm{N}$ fertiliser applications can be added prior to harvest to encourage rapid floral and vegetative development after pruning without negative effects on fruit quality particularly if $\mathrm{N}$ is applied as split applications at the recommended rate for tree size and variety.
\end{abstract}

Keywords: Mango, nitrogen, fertiliser, inflorescence, yield, canopy

\section{INTRODUCTION}

Mangifera indica L. is considered a terminal bearing tree with inflorescences developing on vegetative terminals in the periphery of the canopy (Halle et al., 1978). Maximising the number of terminals on a tree and maintaining healthy terminal buds is critical to optimising flowering (Blakie and Cavanagh, 2003). While photosynthesis regulates the conversion of carbohydrates for plant growth and maintenance of structural components within the tree (Davie et al., 2000), $\mathrm{N}$ fertilization provides resources for proteins and enzymes associated with photosynthesis, shoot elongation, leaf growth and canopy expansion. In addition, while too little $\mathrm{N}$ can limit growth, excessive $\mathrm{N}$ levels can negatively influence the quality of fruit and vigour of the tree (Bally, 2006). In addition, $\mathrm{N}$ in soils is highly mobile and hence can be lost from agricultural systems rapidly so consideration on the appropriate product, rate, application and frequency of timing are also important.

Mango has an annual growth and harvest cycle and therefore it is critical to apply $\mathrm{N}$ fertilizer in relation to tree requirements such as annual nutrient exports (Stassen et al., 2000) and timing associated with the annual phonological cycle. The timing of vegetative

a Email: Paula.Ibell@daf.qld.gov.au 
and floral growth varies with variety and growing location. On the Tablelands in Far North Queensland flowering is an annual event and occurs when vegetative terminals have rested (age-dependent vegetative promoter) and exposed to floral initiation signals such as a change in temperatures (temperature -regulated florigenic promoter)(Davenport, 2007). As a result there are important principles to consider when managing mango canopies to help synchronise vegetative growth, dormancy and flowering.

One of these principles is the timing of $\mathrm{N}$ fertilizer applications. $\mathrm{N}$ is applied at the wrong time in the mangoes' phenological cycle may stimulate vegetative flushing and promote vegetative flushing in competition with flowering and fruiting. This research aims to investigate the effects of different application times of $\mathrm{N}$ directly before harvest to quantify the effect of $\mathrm{N}$ application on yield, fruit quality, canopy size and flower synchronisation within the canopy. It is believed that this information will allow us to better understand the response time and effects of pre-harvest applications of $\mathrm{N}$ fertiliser in two commercial varieties in Far North Queensland.

\section{MATERIALS AND METHODS}

In $2012-2013,53 \mathrm{~kg} /$ ha $\mathrm{N}$ as urea was applied to trees $(156 \mathrm{~g} /$ tree) while in 2014$15,60 \mathrm{~kg} / \mathrm{ha}$ (180 g/tree) was applied as urea (as outlined in the Agrilink Mango Growers Guide for 2-6 m diameter KP and R2E2 trees) (Meurant et al, 1999). The urea was given in the proportions given in Table 1 and applied at the times in Table 2. Potassium (K) fertiliser was applied during fruit development as potassium sulphate between August and December where each year, approximately 3 weeks apart, six applications of 200 grams of potassium sulphate were also applied up until harvest. In March 2013, $2 \mathrm{Kg}$ of gypsum, 500g of magnesium sulphate, 40 grams of boron and was also applied to all trees. Trace elements were applied as a 1\% foliar spray in July 2012-13 as zinc sulphate heptahydrate, iron chelate and solubor.

Table 1. Application rates and proportions at times of application for elemental $\mathrm{N}$ per tree for Kensington Pride and R2E2 mango trees at an orchard in Mareeba, Far North Queensland.

\begin{tabular}{llll}
\hline Treatment & Timing & $\begin{array}{l}\text { Proportion applied (\%) } \\
\text { Pre-harvest }\end{array}$ & $\begin{array}{l}\text { Post-harvest } \\
(\%)\end{array}$ \\
\hline 1 & & & 100 \\
2 & Post-harvest & 50 \\
3 & 2 weeks prior to harvest & 50 & 65 \\
4 & 2 weeks prior to harvest & 35 & 35 \\
5 & 2 weeks prior to harvest & 65 & 65 \\
6 & 4 weeks prior to harvest & 35 & 35 \\
\hline
\end{tabular}

Table 2. Application times for $\mathrm{N}$ fertiliser in Kensington Pride and R2E2 mango trees at an orchard in Mareeba, Far North Queensland.

\begin{tabular}{|c|c|c|c|c|c|}
\hline Year & $\begin{array}{l}\text { Pruning }(\mathrm{P}) / \\
\text { Hedging }(\mathrm{H})\end{array}$ & 4 weeks before & $\begin{array}{l}2 \text { weeks } \\
\text { before }\end{array}$ & Harvest & $\begin{array}{l}\text { Post-harvest } \\
\text { application }\end{array}$ \\
\hline 2012 & & $\begin{array}{l}\text { 19th of } \\
\text { November }\end{array}$ & $\begin{array}{l}\text { 3rd of } \\
\text { December }\end{array}$ & $\begin{array}{l}17 \text { th of } \\
\text { December }\end{array}$ & $\begin{array}{l}\text { 7th of January } \\
2013\end{array}$ \\
\hline 2013 & $\begin{array}{l}\text { (P) 3rd } \\
\text { January } 2013\end{array}$ & $\begin{array}{l}\text { 28th of } \\
\text { November }\end{array}$ & $\begin{array}{l}\text { 11th of } \\
\text { December }\end{array}$ & $\begin{array}{l}\text { 31st of } \\
\text { December }\end{array}$ & $\begin{array}{l}\text { 6th of } \\
\text { February } \\
2014\end{array}$ \\
\hline 2014 & (H) 10 th & 21st of & 8th of & $22 \mathrm{nd}$ of & 5th of January \\
\hline
\end{tabular}




$\begin{array}{llll}\text { February } & \text { November } & \text { December } & \text { December }\end{array}$

\section{Experimental design}

The KP and R2E2 trees were replicated 5 times and set out as a randomised complete block design with 5 replicates; however treatment 1 in the R2E2 trial was only replicated 4 times.

\section{Foliar nutrition}

Soils were characterised at the start of the trial (data not included). Foliar $\mathrm{N}$ and other micro and macro nutrient dry matter concentrations were assessed in June 2013 and 2014. SPAD chlorophyll meter readings were taken from 8 different positions in the canopy including in the upper and lower positions in the north, south, east and west canopy positions in June 2013 and 2014. Initial 2012 foliar $\mathrm{N}$ dry matter (\%) and soil nitrate, prior to treatment application, was $1.5 \%$ and less than $5 \mathrm{mg} \mathrm{kg}^{-1}$ for $0-80 \mathrm{~cm}$ depth, respectively.

\section{Yield and canopy measurements}

Total tree yield was estimated from counts of fruit numbers on trees prior to harvest and an average fruit weight based on 10 fruits from each tree at harvest. Total yield per hectare was then estimated by multiplying the total tree yield $(\mathrm{kg})$ by trees per hectare (156 trees $\mathrm{ha}^{-1}$ ) and divided by 1000 (conversion from kg to tonnes). Canopy voume (V) and canopy surface area (CSA) were estimated using the calculations for $V=\pi r^{2} h$ and CSA $=\pi r^{2}$ respectively. While yield efficiency was calculated as the total tree yield divided by the canopy volume (V). Tree height, skirt height, canopy width and length were measured in June each year once vegetative growth had ceased while canopy height was calculated as tree height minus skirt height.

\section{Fruit quality measurements}

At harvest 10 fruit from each tree was collected and returned to the Centre for Tropical Agriculture in Mareeba for processing. Once back at the facility mangoes were desapped with a bucket of water and mango wash, hot water dipped to $52^{\circ} \mathrm{C}$ and then wiped and placed back into labelled boxes in a ripening room set at $22^{\circ} \mathrm{C}$. Fruit were ripened to eating ripe and then assessed for ground skin colour, lenticel spotting and severity of disease incidence $\left(\mathrm{cm}^{2}\right)$. Prior to eating ripe, fruit was measured for fruit dimensions (length, width and breadth) and weighed. Assessment for ground skin colour was undertaken in 2012 and 2013 using a Konica Minolta spectrophotometer while in the third year (2014) colour was assessed using skin colour classes in the Mango Quality Assessment Manual (Holmes et al., 2009). Lenticel spotting was also assessed using the classes in the Mango Quality Assessment Manual.

\section{Flowering synchronisation and uniformity in canopy development}

To identify if application of $\mathrm{N}$ at different times had any effect on flowering in the season following $\mathrm{N}$ applications, two methods were used to assess inflorescence developmental stages. The first method is referred to as the 'whole tree flower assessment' and the second as the 'canopy branch flower assessment' techniques.

\section{Whole tree flower assessment}

For the whole tree flower assessment method the canopy is arbitrarily divided into four quarters representing north, south east and west quarters of the tree. A count of the number of inflorescences in each flowering stage is then estimated. Categories include inflorescence stages A-C, D-G and H-K within each quarter (Figure 1). The sampling was carried out on three occasions in 2013 and 2014. In 2013 both KP and R2E2 were assessed 
on the following dates $6 / 08 / 2013,21 / 08 / 2013$ and $13 / 09 / 2013$, while in 2014 only R2E2 was assessed on the following dates 12/08/2014,1/09/2014 and 7/10/2014).

The proportion of the terminals in each flowering stage was analysed using a binomial generalised linear mixed model (GLMM) to investigate the effect of treatment ( $\mathrm{N}$ application), tree quarter and the interaction. In addition to the development stage of flowers, the total vegetative terminals, number of inflorescences in each quarter, number of bronze new vegetation, mixed inflorescences (inflorescences with leaves) and the total number inflorescences over the whole canopy were also estimated.

\section{Canopy branch flower assessment}

For this technique each tree was divided into eight segments representing north, south, east and west quarters and upper and lower canopy. After pruning and hedging in 2013 and 2014, a main branch (parent) from the KP trees was selected within each canopy position (of which there were eight) and tagged for future reference. In July of each year after vegetative growth had ceased, three branches (daughters) originating from the selected pruned parent branches were labelled and assessed for flowering stages at different times in each flowering season [2013 (6/08, 21/8 and 16/09) and 2014 $(23 / 07,4 / 8,18 / 8$ and 11/09)]. These assessments aimed to identify if the $\mathrm{N}$ treatments influenced either the development of flowers in time (inter-canopy) or spatially within the tree (intra-canopy). A GLM assuming a multinominal distribution and probit link function was used to compare distributions across flowering stages at 3 time periods in 2013 and 2014.

\section{RESULTS AND DISCUSSION}

\section{Foliar nutrition}

SPAD chlorophyll meter reading in winter 2013 and 2014 taken from 8 canopy positions showed no significant effect of treatment but in 2013 there was significant effect for quarter $(p=0.003)$. In 2014 there was a significant main effect of quarter $(p=0.018)$ and level (upper/lower canopy) ( $p=0.029)$. In both years SPAD readings were higher in the south and west side of the canopies compared to the north. In 2014 SPAD readings were significantly higher in the upper canopy (44.4) than the lower canopy (43.6). There was no significant difference for N dry matter (DM) or any other nutrient in 2013 (1.42\%) or 2014 $(1.37 \%)$ although treatments were all in the adequate range of nutrition for Mango $\mathrm{N}$ dry matter (1 - $1.5 \%$ )(Reuter and Robinson 1997). In 2014, ammonium nitrogen in leaf samples was moderately significant $(\mathrm{p}=0.057)$ where treatment $6(65 \%$ before and $35 \%$ after applied 4 weeks before harvest) had $79 \mathrm{mg} \mathrm{kg}^{-1}$ ammonium $\mathrm{N}$ compared to treatments 1 - 5 which had $67.0,67.7,57.0,58.0$ and $62.3 \mathrm{mg} \mathrm{kg}^{-1}$ ammonium $\mathrm{N}$ respectively. 


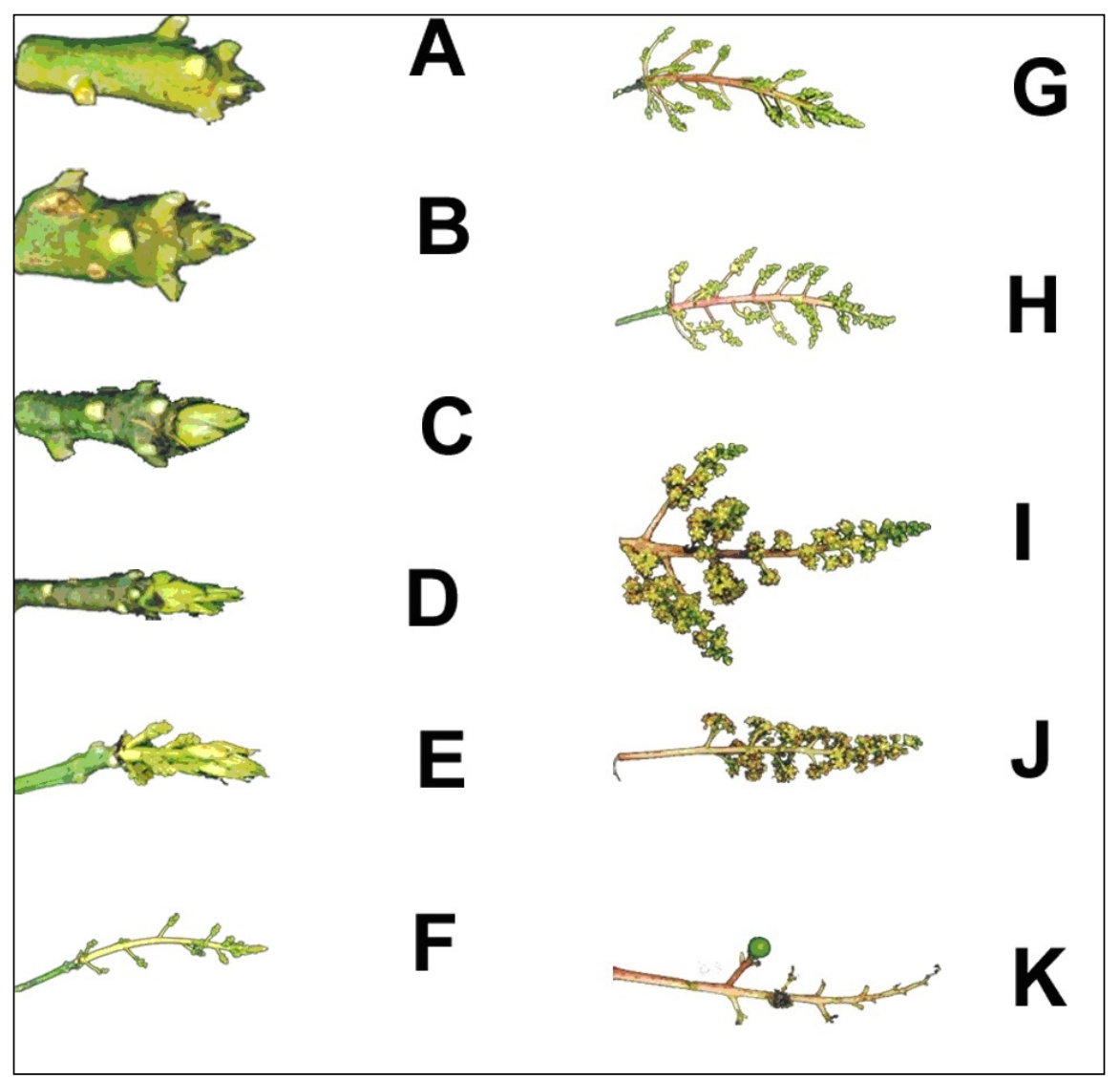

Figure 1: Flower development stages used for the assessment of flower canopy development in N timing trials at South-edge Research Station. Stages are A - Dormant buds; B - Bud swell; C - Bud break : First movement of bud, bud scales appear a lighter green; D - Mouse ears: The developing panicle protrudes beyond the bud scales; E - Elongation: Bud scales have fallen and the panicle is beginning to lengthen); F - Elongation green: Panicle continues to elongate and develop side branchlets however the main stem of the panicle is still green; G - Elongation Red: Panicle branchlets elongate and main stem is a red/pink colour; $\mathrm{H}$ Anthesis: First flowers open, flowers begin to open on the lower panicle first; I - Full bloom: Flowers open on all panicle branchlets except for the tip; J - Fruit set: Fruit set can be seen as a swelling of the light green ovary in the centre of the flower; $\mathrm{K}$ - Flowering completed: Petals and panicle branches dropping along with some fruit drop, pea-sized fruit.

\section{Yield and canopy measurements}

The results indicated that pre-harvest applications of $\mathrm{N}$ did not significantly affect total fruit number, mean fruit weight, yield or fruit weight of either the KP or R2E2 trees. When yields were combined and analysed across each of the 3 years and there was a significant effect of year, for both varieties but only the R2E2 showed a significant effect of treatment on total tree fruit number and yield (Tables 3 and 4). R2E2 canopies were also significantly smaller for canopy surface area and ground surface area for treatment 2 when compared with that of treatments 4 and 5 in 2014.

Table 3: Means, p-values, standard error of the difference (SED) and 95\% least significant difference (LSD) for total fruit number, mean fruit weight, total tree yield, total tree yield (kg tree $\left.{ }^{-1}\right)$, yield $\left(\mathrm{kg} \mathrm{ha}^{-1}\right)$ and yield efficiency combined over three years in a Kensington Pride (KP) orchard in Mareeba, Far North Queensland. 


\begin{tabular}{llllll}
\hline Treatment & $\begin{array}{l}\text { Fruit } \\
\text { number }\end{array}$ & $\begin{array}{l}\text { Fruit } \\
\text { weight }\end{array}$ & $\begin{array}{l}\text { Tree yield } \\
\left(\mathrm{kg} \mathrm{tree}^{-1}\right)\end{array}$ & Yield (t ha-1) & $\begin{array}{l}\text { Yield efficiency } \\
\left(\mathrm{kg} \mathrm{m}^{-3} \text { canopy }\right. \\
\text { volume })\end{array}$ \\
\hline 1 & 86.5 & 515.8 & 43.56 & 6.8 & 1.91 \\
2 & 105.3 & 522.7 & 53.74 & 8.38 & 2.08 \\
3 & 106.0 & 522.0 & 54.32 & 8.47 & 2.05 \\
4 & 98.4 & 542.9 & 52.28 & 8.16 & 2.08 \\
5 & 114.0 & 517.1 & 57.38 & 8.95 & 2.46 \\
6 & 99.6 & 528.7 & 49.86 & 7.78 & 1.99 \\
p-value & 0.685 & 0.624 & 0.693 & 0.693 & 3.348 \\
SED & 16.6 & 16.75 & 8.603 & 1.342 & 0.246 \\
$95 \%$ LSD & 34.7 & 34.95 & 17.945 & 2.799 & 0.51 \\
\hline
\end{tabular}

Table 4: Means, p-values, standard error of the difference (SED) and 95\% least significant difference (LSD) for total fruit number, mean fruit weight, total tree yield (kg tree-1), yield ( $\mathrm{kg} \mathrm{ha}^{-1}$ ) and yield efficiency for combined data over three years in a R2E2 orchard in Mareeba, Far North Queensland.

\begin{tabular}{llllll}
\hline Treatment & $\begin{array}{l}\text { Fruit } \\
\text { number }\end{array}$ & Fruit weight & $\begin{array}{l}\text { Tree yield } \\
\left(\mathrm{kg} \mathrm{tree}^{-1}\right)\end{array}$ & Yield (t ha-1) & $\begin{array}{l}\text { Yield efficiency } \\
\left(\mathrm{kg} \mathrm{m}^{-3} \text { canopy }\right. \\
\text { volume })\end{array}$ \\
\hline 1 & $56.16 \mathrm{~b}$ & 827.4 & $47.37 \mathrm{~b}$ & $7.39 \mathrm{~b}$ & 2.87 \\
2 & $43.33 \mathrm{a}$ & 821.9 & $36.69 \mathrm{a}$ & $5.72 \mathrm{a}$ & 2.37 \\
3 & $52.82 \mathrm{ab}$ & 835.0 & $44.19 \mathrm{ab}$ & $6.89 \mathrm{ab}$ & 2.79 \\
4 & $58.53 \mathrm{~b}$ & 836.5 & $49.49 \mathrm{~b}$ & $7.72 \mathrm{~b}$ & 2.88 \\
5 & $58.53 \mathrm{~b}$ & 796.6 & $47.72 \mathrm{~b}$ & $7.45 \mathrm{~b}$ & 2.52 \\
6 & $55.53 \mathrm{~b}$ & 825.2 & $46.19 \mathrm{~b}$ & $7.21 \mathrm{~b}$ & 2.77 \\
p-value & 0.027 & 0.820 & 0.046 & 0.046 & 0.507 \\
SED & 4.996 & 31.57 & 4.373 & 0.682 & 0.353 \\
$95 \%$ LSD & 9.978 & 63.05 & 8.737 & 1.363 & 0.704 \\
\hline
\end{tabular}

\section{Fruit quality measurements}

Results indicated that different $\mathrm{N}$ timing applications did not significantly affect fruit dimensions, disease at eating ripe, lenticel spot or ground skin colour for KP or R2E2 in either year.

\section{Flowering synchronisation and uniformity in canopy development}

\section{Whole tree inflorescence assessment}

For this method of flower assessment KP did not show any significant difference between the treatments at the whole tree or canopy quarter levels. For R2E2 there was no effect of application time of $\mathrm{N}$ on whole tree or canopy quarter inflorescence estimates, however in 2014 treatments 4 and 6 had increased inflorescences compared to the other treatments (Table 5) although not significantly different to treatments 3 and 5.

Table 5: Means, p-values, standard error of the difference (SED) and 95\% least significant difference (LSD) for R2E2 canopy volume, canopy surface area, ground surface area and total number of terminals for R2E2 trees grown with different nitrogen timing applications.

\begin{tabular}{lllll}
\hline Year & Treatment & $\begin{array}{l}\text { Canopy surface } \\
\text { area }\left(\mathrm{m}^{2}\right)\end{array}$ & $\begin{array}{l}\text { Canopy ground } \\
\text { area }\left(\mathrm{m}^{2}\right)\end{array}$ & $\begin{array}{l}\text { Total } \\
\text { inflorescences }\end{array}$ \\
\hline $2014-15$ & 1 & $30.44 \mathrm{abc}$ & $9.62 \mathrm{abc}$ & $388.0 \mathrm{a}$ \\
& 2 & $27.24 \mathrm{a}$ & $8.47 \mathrm{a}$ & $377.7 \mathrm{a}$
\end{tabular}




\begin{tabular}{llll}
3 & $28.29 \mathrm{ab}$ & $8.93 \mathrm{ab}$ & $413.5 \mathrm{ab}$ \\
4 & $32.26 \mathrm{bc}$ & $10.17 \mathrm{bc}$ & $460.5 \mathrm{~b}$ \\
5 & $34.30 \mathrm{c}$ & $10.87 \mathrm{c}$ & $425.5 \mathrm{ab}$ \\
6 & $27.99 \mathrm{ab}$ & $8.85 \mathrm{ab}$ & $463.2 \mathrm{~b}$ \\
p-value & 0.038 & 0.024 & 0.019 \\
SED & 2.325 & 0.720 & \\
95\% LSD & 4.864 & 1.505 & \\
\hline
\end{tabular}

\section{Canopy and branch flower assessment}

Pre-harvest application of $\mathrm{N}$ in treatments 5, 6, 4 and 2 showed more advanced stages of floral development when compared to the control trees in both 2013 and 2014. There were significant main effects of treatment at all but one time point for KP in the 2013 flowering season however level and quarter were not significant. The results at time 1 $(6 / 08 / 2013)$ showed that there was a tendency for treatment 5 to be more developed (having more flowering stages present in the canopy) and treatment 1 to be less developed. The ranking of the treatments from most developed to least developed was 5, 6, 4, 2 and 1 (p $=0.47)$. At time $2(21 / 08 / 2013)$ the treatment effect was significant $(\mathrm{p}=0.014)$. Treatment 5 was again more developed and treatment 1 to be least developed. The overall ranking of the treatments from most to least developed is 5, 6, 4, 2 and 1 . At time $3(16 / 09 / 2013)$ the treatment effect was significant $(p=0.016)$. There was a wider range of flowering stages from $A$ through to $K$ including a new stage vegetative $(V)$. Treatment 5 was again considered to be more developed. The overall ranking of the treatments from most developed to least developed was 5, 6, 4, 1 and 2 (Figure 1a).

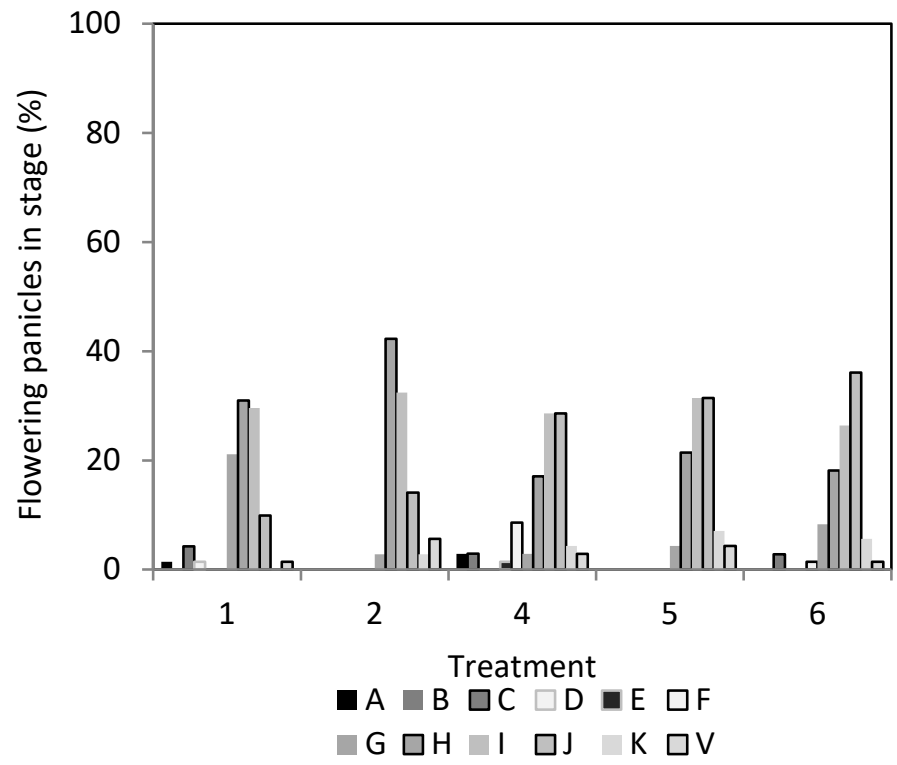

(a) 


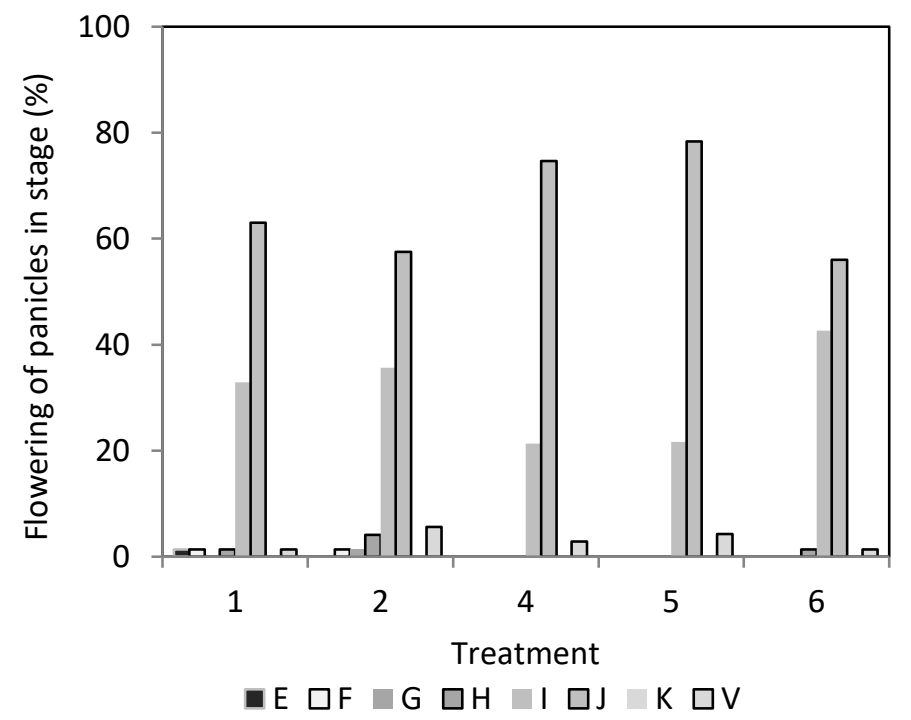

(b)

Figure 1: Percentage of panicles in flowering stages at (a) time $3(16 / 9 / 2013)$ and (b) time 4 $(11 / 9 / 2014)$ in Kensington Pride trees under different Nitrogen timing applications in Mareeba, Far North Queensland.

In the second year of canopy branch inflorescence assessment results indicated a significant effect of treatment on flowering stages within the orchard $(\mathrm{p}<0.001$ for treatment at time 1, 3 and 4). At time 1, treatment 6 had an increased percentage of inflorescences in more mature stages of floral development, while treatment one was least developed. Treatment 5 at this time had $85 \%$ of inflorescences at the same stage suggesting good flower synchronisation within the canopy for this treatment. At time 2 there was a significant effect of level where inflorescences in the lower canopy were more developed than inflorescences in the upper canopy $(\mathrm{p}<0.039)$. At time 3 , as well as a significant treatment effect, there was a significant interaction of quarter and treatment at time $3(p<0.001)$ which indicated that the majority of inflorescences in treatment 1 were in stage $\mathrm{E}$ but for treatment 4 they were at stage $\mathrm{F}$ and for treatment 5 stage $\mathrm{G}$. Flowers in the north quarter of treatment 2, 4 and 6 were mainly at stage $\mathrm{G}$ while treatments 1 and 5 were at stage E. At time 4 treatments 4 and 5 had all flowers at stage I or higher, while treatment 1 still had flowers at stage $\mathrm{E}$ and $\mathrm{F}$ (Figure $1 \mathrm{~b}$ ). At time 4 there was also a significant effect of canopy quarter $(\mathrm{p}<0.001)$ where the south quarter was less developed $(50 \%$ a stage I or less developed) compared to the north quarter which had nearly $80 \%$ of terminals at stage J.

\section{CONCLUSIONS}

The role of nitrogen in tree growth is associated with regulation of carbohydrate assimilation in the canopy. The products of assimilation provide resources which are stored in tree roots, trunk and branches. The capacity and timing of release of stored resources has an important role for growth in spring. Root activity prior to bud break has been linked to early mobilisation of reserves in spring (Hendry et al., 1993). These results have shown that the addition of $\mathrm{N}$ fertiliser prior to harvest had a positive influence on seasonal vegetative growth although the responses were variety specific. In addition, by providing $\mathrm{N}$ resources 2 to 4 weeks prior to harvest (as split applications) we may encourage early and synchronous floral development in canopy the following spring. This may provide some contingency for an earlier flowering window if cool induction seasons are short or where humid, wet weather may reduce effective fertilisation (Barker and Mills, 1980). Therefore, 
$\mathrm{N}$ fertiliser applications added prior to harvest can encourage early floral development after pruning without negative effects on fruit quality particularly if $\mathrm{N}$ is applied as split applications at the recommended rate for tree size and variety.

\section{ACKNOWLEDGEMENTS}

The authors wish to acknowledge the funding support by the Australian Centre for Agricultural Research (ACIAR) for operating funds to complete this research. We also acknowledge the Department Agriculture and Fisheries staff and casuals involved in maintenance of the orchards and those whom assisted with data collection during this trial.

\section{LITERATURE CITED}

Bally, I. E. (2006) The effect of preharvest nutrition and crop load on fruit quality and postharvest disease in Mango (Mangifera indica L.). PhD thesis, University of Queensland.

Barker, A.V., and Mills, H.A. (1980) Ammonium and nitrate nutrition of Horticultural crops. Horticultural Reviews, Volume 2, AVI Publishing, Connecticut.

Blakie, S., Cavanagh P. (2003) Operation K, A production guide for Mango growers in Northern Australia.

Davenport, T.L. (2007) Reproductive physiology of mango. Braz. J. Plant Physiol., 19 (4):363-376.

Davie, P.J.C., Stassen, P.J.C., Grove, H.G. (2000) Starch reserves in the mango tree.in the Proceedings of the Sixth International Symposium on Mango. Volume 1. Ed. Subhadrabandhu, S., Pichakum, A. ISHS

Halle, F., Olderman, R.A.A., Tomlinson, P.B. (1978) Tropical Trees and Forests - An Architectural Analysis. Springer-Verlag, New York.

Holmes, R., Hofman, P., Barker, L. (2009) Mango quality assessment manual. A guide to assessing the postharvest quality of Australian Mangoes. State of Queensland, Department of Economic Development and Innovation. Brisbane.

Muerant, N., Kernot, I. (1998) Mango Information Kit. The State of Queensland, Department of Primary Industries, Brisbane.

Normand, F., Jannoyer, M., Barantin, P., Damour, G., Dechazal, M., Mialet-Serra, I., Clement, S., Verdeil, J., Escoute, J., Sonderegger, N., Legros, S., Lagier, S., Jourdan, C and Davrieux, F. (2006) Nature, location and seasonal changes of non-structural carbohydrates in Mango in Carbon storage in coconut, oil palm, rubber and mango: origins, dynamics and consequences for plantation management. Proceedings - Final meeting of ATP reserves no 11/2002, Montpellier, France. CIRAD, IRNA.

Reuter, D.J., and Robinson, J.B. (1997) Plant analysis, an interpretive manual, 2nd edition. CSIRO, Collingwood.

Stassen, P.J.C, Grove, H.G., Davie, S.J. (2000) Uptake, distribution and requirements of macro elements in 'Sensation' mango trees. Proc. Sixth Int'l Mango Symposium, Acta. Hort. 509, ISHS, 2000.

Young, T.W., and Coo, R.C.J. (1974) Increasing yield of 'Parvin' and 'Kent' Mangos on Lakewood sand by increased nitrogen and potassium fertilization. Florida Agricultural Experiment Stations Journal Series, No. 5650. 